\title{
Portrait of Constitutional Question Mechanisms in Judicial Review Practices in the Constitutional Court from the Perspective of Prophetic Law Paradigm
}

\author{
Mustofa Lutfi ${ }^{1 *}$ \\ ${ }^{1}$ Universitas Islam Negeri Maulana Malik Ibrahim Malang, Indonesia \\ ${ }^{*}$ Corresponding author.Email: mustafalutfi@syariah.uin-malang.ac.id
}

\begin{abstract}
The constitutional question mechanism in the constitutional review authority in the Constitutional Court (MK) has not been adapted so that it can result in the constitutional rights of citizens not being comprehensively protected. Substantive justice based on the One God (transcendent justice) has not been accommodated properly. The focus of this paper is to look at the constitutional question mechanism in the judicial review practice in the Constitutional Court based on the perspective of the Prophetic Law Paradigm. This type of research is a normative juridical study using a statutory approach and a conceptual approach. The method of collecting legal materials was carried out through literature study and analyzed using qualitative juridical analysis methods. The results and findings of the study indicate that the institutionalization of the constitutional question mechanism can be realized by expanding the constitutional review authority in the Constitutional Court. This expansion of authority can be carried out by changing the Constitutional Court Law, without making changes to the 1945 Constitution. The prophetic law paradigm can be used as an alternative perspective to revive the spirit of justice based on One God (transcendent justice) in the practice of constitutional testing in the Constitutional Court, especially in implementing mechanisms constitutional question.
\end{abstract}

Keywords: constitutional court, constitutional review, Prophetic Law Paradigm.

\section{INTRODUCTION}

The Constitutional Court (MK) was born based on the third amendment to the 1945 Constitution of the Republic of Indonesia (UUD 1945). The Constitutional Court in exercising judicial power normatively is also regulated in Law No. 24 of 2003 concerning the Constitutional Court and has been amended by Law No. 8 of 2011 concerning Amendments to Law No. 24 of 2003 concerning the Constitutional Court (MK Law). The Constitutional Court as a constitutional court stands on the basis of the assumption that there is constitutional supremacy which is the highest law that underlies or underlies state activities as well as a parameter to prevent the state from acting unconstitutional [1]. The Constitutional Court is designed to ensure that the 1945 Constitution is truly incarnated and adhered to in its implementation, including ensuring that the constitutional rights of citizens are truly respected, protected, and fulfilled in the practice of state administration [2]. The purpose of establishing the Constitutional Court is in line with the function of the Constitutional Court as The Guardian of
Constitution or as the guardian of the constitution. The Constitutional Court is often referred to as a constitutional judiciary in which this state organ has the authority to resolve legal disputes based on the constitution [3].

The realization of the objectives and functions of the existence of the Constitutional Court is then realized through the powers given to the Court. The authority of the Constitutional Court is stated in Article 24C paragraph (1) of the 1945 Constitution which states that: "The Constitutional Court has the authority to judge at the first and last levels whose decisions are final to examine laws against the Constitution, decide disputes over the authority of state institutions whose authority is given by The Constitution, decides the dissolution of political parties and decides on disputes over the results of general elections" [4].

The Constitutional Court currently has several powers that have been mentioned in the constitution, but if you look further, the only authority of the Constitutional Court that is directly related to the 
protection and fulfillment of citizens' constitutional rights is the authority to examine laws against the 1945 Constitution or the authority for constitutional review. Unfortunately, the authority for constitutional review in the Constitutional Court does not clearly state the scope of norm testing, whether it is included in the variant of testing abstract norms or testing concrete norms (constitutional question).

The 1945 Constitution and the Constitutional Court Law only state that the Constitutional Court has the authority to judge at the first and last levels whose decisions are final to examine laws against the 1945 Constitution [5]. The constitutional review authority in the Constitutional Court which does not mention provisions to test concrete norms related to cases in court (constitutional question) is then interpreted that constitutional testing in the Constitutional Court is limited to testing abstract norms.

The legal politics of the formation of the Constitutional Court and the formulation of its powers in the process of amending the 1945 Constitution show that there is hardly any discussion on the scope of norm testing. The magnitude of the weight of the amendments to the 1945 Constitution carried out in four stages of amendment (from 1999-2002) may be the cause, so that the drafters of the amendments to the 1945 Constitution did not have time to discuss, let alone formulate material about the scope of constitutional review when discussing and formulating Article 24C of the 1945 Constitution [6].

Constitutional protection also includes protection for citizens from arbitrary application of the law by the court, namely when the court applies laws that are contrary to the constitution, thus detrimental to the constitutional rights of citizens. The constitutional question mechanism is one of the efforts to prevent the loss of constitutional rights of citizens due to the application of laws that are contrary to the constitution. A constitutional question is said to be able to prevent arbitrariness in law enforcement because a constitutional question is a mechanism related to testing the constitutionality of a law. A judge who is trying a case assesses or has doubts about the constitutionality of the law in force, so that the judge can raise his constitutional questions to the Constitutional Court [2].

The condition that the constitutional question mechanism has not been adopted in the Constitutional Court shows that the constitutional review system in Indonesia still has inequalities because it is only able to reach abstract norm review. This condition has resulted in a narrow space for constitutional review in Indonesia and does not protect the constitutional rights of citizens.

The limitation of the constitutional review authority only in the abstract review will make violations of the constitution cannot be maximally processed. The constitutional question then becomes important to serve as an alternative mechanism for the authority of the Constitutional Court when viewed from the importance of providing comprehensive protection of the constitution [7].

Even though the Constitutional Court is only given the authority for constitutional review of abstract norms, in practice many petitions submitted to the Constitutional Court are formally in the form of judicial review, but substantially including constitutional questions, on the grounds that the petitioners have suffered constitutional losses because they have been tried and even being punished based on the provisions of the law whose constitutionality is doubtful [8].

Several cases of requests for judicial review include the review of the Criminal Code in Case Number 013022 / PUU-1V / 2006 filed by Eggi Sudjana and Pandopatan Lubis, Case Number 6 / PUU-V / 2007 filed by Panji Utomo, Case Number 14 / PUU-VI / 2008 filed by Risang Bima Wijaya and Bersihar Lubis, and Case Number 7 / PUU-VII / 2009 filed by Rizal Ramli. All petitions in these cases have been tried and convicted, and have even served sentences before submitting an application to the Constitutional Court [9].

Geographically and sociologically, Indonesia is a country where the majority of the population is Muslim [10]. Indonesia as a Muslim country, during the decades of the seventies and eighties there was an awareness of the crisis in the field of modern science which was considered value-free and free of other interests [11]. The phenomenon of the scientific crisis was then responded to with the idea of the need for an ethical dimension in the development of science. One of the scientific paradigms that has an ethical dimension in it is the prophetic paradigm. In relation to legal science, this paradigm is also often referred to as the prophetic legal paradigm.

The urgency of the description above elaborates the values in the paradigm of prophetic law as an alternative perspective that can be used to review the need for implementing a constitutional question mechanism on the constitutional review authority of the Constitutional Court, so that later the Constitutional Court can carry out its function optimally as the guardian of the constitution.

\section{RESEARCH METHOD}

This type of research uses Normative Juridical research. This study uses 2 approaches, namely, a statute approach and a conceptual approach. Sources of legal materials used in this research are: (1) Primary legal materials consisting of the 1945 Constitution, the Constitutional Court Law, theConstitutional Court Decisions (2) Secondary legal materials which include books, journals, and documents that review constitutional matters. question, and about prophetic law. (3) Tertiary 
legal materials consisting of a large Indonesian dictionary, a legal dictionary and an English dictionary.

The method of collecting legal materials used in this research is literature study, namely by tracing books, journals, and documents related to constitutional questions and prophetic law. The analytical method used in this research is qualitative juridical analysis method [12] This is because analyzing and interpreting in depth about legal materials as usual normative legal research. The results of this analysis aim to produce an objective assessment in order to answer the problems in the research, namely related to how the constitutional question is applied in the constitutional review authority of the Constitutional Court in the perspective of a prophetic law paradigm.

\section{DISCUSSION}

\subsection{Portrait of the Institutionalization of the Constitutional Question Mechanism in Indonesia}

A constitutional question is a constitutional question raised by a judge from a public court, that is, when a general court judge must give a decision on a case, if he believes that the applicable law is unconstitutional, or doubts its validity, he can refer the question to the constitutional court. General court judges can postpone the examination and question it in the constitutional court. The constitutional court will not give a verdict on the case, but will impose limits on the constitutionality of the law. The general court judges will then determine the case based on the Court's decision [13].

The constitutional question authority which is included in the scope of constitutional review is not held by the Constitutional Court at least until now. The authority of the constitutional question has not been explicitly stated in the 1945 Constitution or in the Constitutional Court Law. The constitutional review authority possessed by the Constitutional Court is only formulated briefly in Article 24C paragraph (1) of the 1945 Constitution, which reads: "The Constitutional Court has the authority to judge at the first and last levels whose decisions are final to test laws against the Basic Law". Article 10 paragraph (1) of the Constitutional Court Law also only states that the Constitutional Court has the authority to judge at the first and last levels whose decisions are final to test the law against the 1945 Constitution.

Seeing the actual condition and development of cases submitted and examined in the Constitutional Court, as discussed in the previous chapter, many legal experts have recommended that the Constitutional Court be given the authority to adjudicate constitutional questions [14]. Given the importance of protecting the constitutional rights of citizens, constitutional questions can be an effective means of controlling power, both at the state and community levels. Moh. Mahfud MD et al explained [2], at least there are three important advantages that can be taken from the application of the constitutional question mechanism if it is to be adopted in Indonesia: To maximize the respect, protection and fulfillment of citizens' constitutional rights.

Judges are not forced to apply the applicable law to a case in which according to their belief the law is contrary to the constitution (UUD 1945) [15]. For Indonesia, which formally and in the legal tradition do not adhere to the stare dicisis principle or precedent principle, this right will help to form a unity of view or understanding among judges outside the constitutional judges regarding the importance of upholding the principle of legal constitutionality not only in the process of its formation but also in its application. The urgency for a clear and binding regulation related to the institutionalization of the constitutional question mechanism on the constitutional review authority of the Constitutional Court, so that everyone can get legal certainty guarantees in accordance with the constitutional rights in the 1945 Constitution. There is legal certainty so that the implementation of constitutional democracy that upholds the supremacy of the constitution can be carried out properly.

An alternative way of institutionalizing the constitutional question mechanism can be implemented by expanding the authority of the Constitutional Court. This expansion of authority can be done through amendments to the Constitutional Court Law. Even though the form is in the form of a question, the construction of thought and substance contained in the constitutional question is the review of the law against the 1945 Constitution, so that this mechanism can have an umbrella on the authority of constitutional review and does not violate the authorities stipulated in the 1945 Constitution

The expansion of the Constitutional Court's authority in examining laws against the 1945 Constitution can be done by adding provisions to Article 51 paragraph (1) of the Constitutional Court Law regarding the legal standing of judges at the general court to ask questions to the Constitutional Court regarding the constitutionality of the law that will be used in deciding cases that are currently on trial if doubt arises. Article 51 paragraph (1) of the Constitutional Court Law states that: (1) "Petitioner is a party who considers that his constitutional rights and / or authorities have been impaired by the enactment of the law, namely: a). individual Indonesian citizens, b). indigenous peoples as long as they are still alive and in accordance with the development of society and the principles of the Unitary State of the Republic of Indonesia as regulated in law; c). public or private legal entities; or d). state institutions [16].

There are two things that can be concluded from this provision. First, it is as if the legislators assumed that 
violations of constitutional rights only occurred because of the norms of the law. Second, parties who have the legal standing (persona standi in judicio) to apply for a review are only parties whose constitutional rights have been directly impaired by the enactment of this law [2].

The explanation above shows that there is no legal standing for judges at the general court who wish to apply for a constitutional question. There is no regulation regarding this matter because the judge who is the petitioner for the constitutional question case is essentially not harmed by the enactment of the law [11]. Restrictions on legal standing cause judges to be forced to apply statutory norms that are inconsistent with the constitution. John Marshall said that judges should not be forced to implement laws that contradict the constitution, because the judge has sworn that he will uphold the constitution [15].

The constitutional question mechanism can also be carried out by amending the Constitutional Court Law, for example by adding a provision in Section eight ("Review of the Law against the Basic Law"), that court judges from the General Courts, Religious Courts, Military Courts, or Administrative Courts The state, if in deciding the case that is being judged in doubt about the constitutionality of the law applicable to that case, it can ask the Constitutional Court questions about the constitutionality of the law in question before the decision on the case is passed. If the Constitutional Court states that the law is constitutional, the examination of the case will continue. On the other hand, if the Constitutional Court states that the law in question is unconstitutional, then the case is declared null and void by law [17].

\subsection{Implementation of the Constitutional Question Mechanism on Constitutional Examination at the Constitutional Court in the Perspective of the Prophetic Law Paradigm}

The Constitutional Court has affirmed itself as a guardian of democracy that upholds the principles of justice and upholds substantive justice in each of its powers and decisions [18]. This is in line with the mandate of Article 24 paragraph (1) of the 1945 Constitution. According to the Constitutional Court, the value of justice to be achieved is not merely procedural justice [11], but real justice, justice that is substantial, essential, and recognized, felt, and lives in society. Roger Cotterrell stated that it is the judge's duty to understand, explore the values and a sense of justice, which already exist in society. Justice does not only represent or belong to the majority, but also belongs to at the same time protects the minority [19].

The values of substantive justice attempted to be implemented by the Constitutional Court are in accordance with the fifth principle of Pancasila, "Social justice for all Indonesian people". The Constitutional
Court interpreted the law based on the spirit of social justice and substantive justice which made the constitutional text not the main center, but paid attention to the context and contextualization of an article with current conditions [20].

The application of the values of justice has also been described in CHAPTER II Principles of Implementing Judicial Power Article 2 paragraph (1) and (2) Law of the Republic of Indonesia Number 48 of 2009 concerning Judicial Power which states: (1) Judgment shall be conducted "FOR JUSTICE BASED ON ONE ALMIGHTY GOD". (2) State courts implement and enforce law and justice based on Pancasila.

This can also be seen in each head of the Constitutional Court's decision which reads, "For Justice Based on One Godhead". Bismar Siregar stated that it could be interpreted that in determining the verdict, first of all a judge merits to Allah SWT. It is in His name that the verdict is pronounced. He swore in the name of God Almighty [21]. Observing the laws and each head of the Constitutional Court Decisions, the essence of justice to be decided is transcendental justice. Transcendental justice is justice that is full of meaning and divine values that animate in a decision. For judges, the justice to be decided is not only accountable horizontally to fellow human beings, but also accountable vertically to God Almighty [11].

Transcendental justice in the paradigm of prophetic law is also in accordance with the value of social justice in the five principles of Pancasila, so that basically the enforcement of social justice is not just a form of social contract but also a responsibility towards God. Social justice in a democratic society becomes an obligation, where social justice is an important element for the formation of peace and welfare [22]. The establishment of the Constitutional Court is also an embodiment of the second principle of Pancasila "Just and Civilized Humanity" in the context of protecting the constitutional rights of citizens. The prophetic law paradigm calls this human value as humanization. Humanization is a constructive meaning of the lafadl "amar ma'ruf", the original meaning of which advocates or upholds virtue [23]. The existence of human values related to the respect for his "degree and dignity" as a human being, it is hoped that humans are free from slavery and other things [24]. This human liberation in the paradigm of prophetic law is called liberalization, which then encourages the presence of a prophetic responsibility to liberate humans from cruelty, poverty, violence, domination of oppressive structures and the life of false consciousness [25]. The existence of this liberation is also a manifestation of human rights in social life.

Observing the explanations that have been mentioned above, it can be understood that the formation of the Constitutional Court is also an embodiment of the second principle of Pancasila in order to protect the 
constitutional rights of citizens which are then very closely related to the dimensions of humanization and liberalization in the paradigm of prophetic law, so that the paradigm of prophetic law is very in line with the values applied by the Constitutional Court as the guardian of constitution. Then the next question is, is in reality the Constitutional Court is in accordance with the values of transcendental justice and respect for the constitutional rights mentioned above?

The idea of establishing the Constitutional Court which has the authority of constitutional review at least has played a significant role in strengthening the constitutional rights of citizens [26], however, as explained in the previous discussion, the constitutional review authority of the Constitutional Court is currently limited to the authority of abstract review. The constitutional review authority of the Constitutional Court has not reached a concrete review or constitutional question [14]

From a legal standpoint, the limited authority of the Constitutional Court could cause problems because it is considered to limit the human rights of justice seekers. The constitutional question then becomes important to serve as an additional authority for the Constitutional Court in order to bring justice to citizens [7].

The urgency of implementing a constitutional question can also be seen from the perspective of the prophetic law paradigm. This paradigm can be used as a new alternative in reviving the spirit of upholding justice based on the one and only God in the judiciary, especially the Constitutional Court. The development of the application of the prophetic legal paradigm can then be a solution to provide legal certainty and justice in accordance with legal objectives [27].

In order to realize these legal objectives, as explained in the previous discussion, the constitutional question mechanism must be institutionalized to expand the Constitutional Court's authority in examining laws against the 1945 Constitution. in the 1945 Constitution. The amendment of this law is intended to create legal certainty for the community, especially justice seekers. The institutionalization of a constitutional question mechanism was also carried out in order to create real justice, which is in accordance with the values in society. This real justice is justice that breathes a prophetic spirit, or transcendental justice (justice based on the one and only deity) which comes from the law of Allah in the alQur'an.

\section{CONCLUSION}

The fact that the constitutional question mechanism has not been adopted in the Constitutional Court shows that the constitutional review system in Indonesia still has imbalances because it is only able to reach abstract norm review. The existence of this imbalance makes the constitutional rights of citizens not fully protected, so it is necessary to institutionalize the authority to examine concrete norms (constitutional question) in constitutional review at the Constitutional Court. The institutionalization of the constitutional question mechanism can be realized by expanding the authority for constitutional review in the Constitutional Court. This expansion of authority can be done by changing the Constitutional Court Law, without making changes to the 1945 Constitution. The prophetic law paradigm can be used as an alternative perspective in realizing the values of justice and the fulfillment of human rights in accordance with the basis of the state and national philosophy, especially in the practice of constitutional review in the Constitutional Court. so that the Constitutional Court can carry out its overall function in protecting the constitutional rights of citizens, especially those related to testing concrete norms related to the litigation process in court (constitutional question).

\section{REFERENCES}

[1] M. Lutfi, Hukum sengketa pemilukada di Indonesia: gagasan perluasan kewenangan konstitusional Mahkamah Konstitusi, Cet. 1. Yogyakarta: UII Press, 2010.

[2] M. M. MD, J. Hamidi, I. D. G. Palguna, M. A. Syafaat, and M. Lutfi, Constitutional Question Alternatif Baru Pencarian Keadilan Konstitusional. Malang: UB Press, 2010.

[3] A. Syahrizal, Peradilan konstitusi: suatu studi tentang adjudikasi konstitusional sebagai mekanisme penyelesaian sengketa normatif. Jakarta: Pradnya Paramita, 2006.

[4] A. Y. Sulistyawan and I. P. E. Cakra, 'Examine The Constitutionality Of Regulations Under Laws That Are Not Contrary To The Law But Contrary To The Constitution', Administrative Law and Governance Journal, vol. 3, no. 1, pp. 104-113, Mar. 2020, doi: 10.14710/alj.v3i1.104-113.

[5] M. H. Fakhrazi, 'Perluasan Wewenang Mahkamah Konstitusi Dalam Memutus Sengketa Kewenangan Antar Lembaga Negara Hingga Lembaga Pemerintahan Tingkat Pusat dan Daerah', STAATSRECHT: Indonesian Constitutional Law Journal, vol. 1, no. 1, Art. no. 1, Jan. 2017, doi: 10.15408/siclj.v1i1.4574.

[6] J. Asshiddiqie, Konstitusi Bernegara Praksis Kenegaraan Yang Bermartabat Dan Demokratis. Malang: Setara Press, 2015.

[7] H. Setiawan, 'Rekonseptualisasi Kewenangan Mahkamah Konstitusi Dalam Upaya Memaksimalkan Fungsi Mahkamah Konstitusi Sebagai the Guardian of Constitution', masters, Fakultas Hukum, 2017.

[8] I. D. G. Palguna, 'Constitutional Complaint and the Protection of Citizens the Constitutional Rights', Constitutional Review, vol. 3, no. 1, Art. no. 1, Aug. 2017, doi: 10.31078/consrev311. 
[9] J. Hamidi and M. Lutfi, 'Constitutional Question (Antara Realitas Politik dan Implementasi Hukumnya)', Jurnal Konstitusi, vol. 7, no. 1, Art. no. 1, May 2016, doi: $10.31078 / \mathrm{jk} \% \mathrm{x}$.

[10] 'Manajemen Pendidikan Moderasi Beragama Di Era Digital | Icrhd: Journal of Internantional Conference on Religion, Humanity and Development', Accessed: Nov. 17, 2020. [Online]. Available: https://confference.iainptk.ac.id/index.php/icrhd/a rticle/view/17.

[11] M. Syamsuddin, Ilmu Hukum Profetik Gagasan Awal, Landasan Kefilsafatan Dan Kemungkinan Pengembangannya Di Era Postmodern, 1 cet 1. Yogyakarta: Pusat Studi Hukum UII, 2013.

[12] A. K. Muhammad, Hukum dan penelitian hukum. Bandung: Citra Aditya Bakti, 2004.

[13] V. F. Comella, 'The European model of constitutional review of legislation: Toward decentralization?', Int J Const Law, vol. 2, no. 3, pp. 461-491, Jul. 2004, doi: 10.1093/icon/2.3.461.

[14] H. Zoelva, 'Constitutional Complaint Dan Constitutional Question Dan Perlindungan HakHak Konstitusional Warga Negara', Jurnal Media Hukum, vol. 19, no. 1, Art. no. 1, 2012, Accessed: Nov. 17, 2020. [Online]. Available: https://journal.umy.ac.id/index.php/jmh/article/vie w/1984.

[15] E. Chemerinsky, Constitutional Law: Principles and Policies. New York: Aspen Publishers, 2006.

[16] S. Hasanah, 'Ulasan lengkap: Pengertian Legal Standing Terkait Permohonan ke Mahkamah Konstitusi', hukumonline.com/klinik. https://www.hukumonline.com/klinik/detail/ulasa $\mathrm{n} / 1 \mathrm{t} 581 \mathrm{fe} 58 \mathrm{c} 6 \mathrm{c} 3 \mathrm{ea} /$ pengertian-legal-standingterkait-permohonan-ke-mahkamah-konstitusi/ (accessed Nov. 17, 2020).
[17] I. D. G. Palguna, Pengaduan Konstitusional (constitutional complaint) : upaya hukum terhadap pelanggaran hak-hak konstitusional warga negara / Oleh I Dewa Gede Palguna | OPAC Perpustakaan Nasional RI. Jakarta: Sinar Grafika, 2013.

[18] Mahkamah Konstitusi, Laporan Tahunan Mahkamah Konstitusi Republik Indonesia. Jakarta: Mahkamah Konstitusi RI, Sekretariat Jenderal dan Kenpaniteraan MKRI, 2009.

[19] R. B. M. Cotterrell, The Politics of Jurisprudence: A Critical Introduction to Legal Philosophy. University of Pennsylvania Press, 1992.

[20] M. Ali, 'Mahkamah Konstitusi dan Penafsiran Hukum yang Progresif', Jurnal Konstitusi, vol. 7, no. 1 , Art. no. 1, 2010, doi: 10.31078/jk\%x.

[21] B. Siregar, Hukum hakim dan keadilan Tuhan. Gema Insani Press, 1995.

[22] R. Fatihin, 'Keadilan Sosial dalam Perspektif AlQur'an Dan Pancasila', Panangkaran: Jurnal Penelitian Agama dan Masyarakat, vol. 1, no. 2, Art. no. 2, Dec. 2017, doi: 10.14421/panangkaran.2017.0102-06.

[23] Kuntowijoyo, Muslim Tanpa Masjid - Esai-Esai Agama, Budaya, dan Politik dalam Bingkai Strukturalisme Transendental. Bandung: Mizan, 2001.

[24] N. Madjid, Islam: Doktrin \& Peradaban. Jakarta: Gramedia Pustaka Utama, 2019.

[25] H. Muttaqin, 'Menuju Sosiologi Profetik', Jurnal Sosiologi Reflektif, vol. 10, no. 1, Art. no. 1, Sep. 2016, doi: 10.14421/jsr.v10i1.1147.

[26] K. Kartono, 'Politik Hukum Judicial Review Di Indonesia', Jurnal Dinamika Hukum, vol. 11, no. 0, Art. no. 0, Mar. 2011, doi: 10.20884/1.jdh.2011.11.Edsus.258.

[27] S. Rahardjo, Masalah Penegakan Hukum Suatu Tinjauan Sosiologis. Bandung: Sinar Baru, 1986. 